\title{
ALGAL INDICATION OF POLLUTION IN THE LOWER JORDAN RIVER, ISRAEL
}

\author{
BARINOVA, S. ${ }^{1}{ }^{*}-$ TAVASSI, M. ${ }^{2}-$ GLASSMAN, H. ${ }^{2}-$ NEVO, E. ${ }^{1}$ \\ ${ }^{1}$ The Algology Laboratory in the Institute of Evolution, University of Haifa Mount Carmel, \\ Haifa 31905, Israel (phone: +972-4-8249697; fax: +972- 4-8246554) \\ ${ }^{2}$ Israel Nature and Parks Authority, Givat Shaul, Jerusalem 95463, Israel \\ *Corresponding author \\ e-mail: barinova@research.haifa.ac.il \\ (Received $14^{\text {th }}$ April 2008 ; accepted $19^{\text {th }}$ January 2010)
}

\begin{abstract}
The Lower Jordan River is one of the most polluted in Israel. We used algal bio-indicators to monitor pollution levels in the dry and rainy seasons in order to assess a self-purification capacity of the aquatic ecosystem. We used 135 species of algae and cyanobacteria as indicators of $\mathrm{pH}$, salinity, and organic pollution. The indices of saprobity ( $\mathrm{S}$ and EPI), river pollution, RPI, and toxicity, BI testify to a greater anthropogenic impact in the lower section, partly owing to influx of pollutants with rain water during the wet season. The aquatic ecosystem state index (WESI) indicates low self-purification activity of biotic communities in this part of the river flow. Multiple Regression Analysis highlighted salinity and trophic elements as the major impact factors for algal diversity. A combination of bio-indication metod, including new integral indices and statistic analysis, and bioassey were found most efficient for monitoring of river ecosystems in Israel.
\end{abstract}

Keywords: Lower Jordan River, water quality, algal bio-indication, season, Israel

\section{Introduction}

During the last millennium, aridity increases in the Mediterranean Region leading to a loss of water resources, which is aggravated by the ever increasing anthropogenic impact (Körner et al., 2005). At the some time, this threatening situation places high demands on monitoring of water resources. However, in such countries as Israel, the hydrobiological indicators were scarcely used so far (Israel Ministry of the Environment, 2005). Yet self-purification of water bodies depends on aquatic biota and mainly on algae as the primary producers. Therefore, algal diversity is indicative of the ecological and sanitary status of the river as well as the self-purification potentials (Janauer and Dokulil, 2006). Our approach is based on bio-indication of algal habitats, including not only the diversity, but also the density of each indicator species. The assessments of aquatic ecosystems based on algological indicators are widely used (Whitton and Rott, 1995; WFD, 2000; Barinova et al., 2006a), but their potentials are not as yet fully recognized. In particular, mapping of water quality domains based on the saprobity indices, obtained from the analysis of algal communities (Sumita, 1986; Watanabe et al., 1986), has been efficient in our studies of the Upper Jordan River (Lipkovsky et al., 2007) and can be applied to the Lower Jordan River as well.

Algae have long been identified as valuable indicators in the bio-monitoring of stream and river ecosystems (Kolkwitz and Marsson, 1908 altered by Hill et al., 2000). More recently, bio-monitoring has been applied to a variety of water quality problems (Hill et al., 2000; Potapova and Charles, 2003). Algal communities provide an integrated measure of water quality as experienced by the aquatic biota and have many

APPLIED ECOLOGY AND ENVIRONMENTAL RESEARCH 8(1): 19-38. http://www.ecology.uni-corvinus.hu • ISSN 15891623 (Print) • ISSN 17850037 (Online) (C) 2010, ALÖKI Kft., Budapest, Hungary 
biological attributes that make them ideal for biological monitoring. About 100 algal species were founding in the Lower Jordan River (Ehrlich, 1995; Lange-Bertalot in Nevo and Wasser, 2000; Rayss, 1951), but their potentials for algal bio-monitoring were not realized so far.

\section{Study area}

The Jordan River is the largest river in Israel, divided into the upper and lower reaches, with the Lake Kinneret in between. The Upper Jordan River discharges into the Lake Kinneret. The outlet from the lake is blocked by the Alumot-dam, which has not been overflowed since 1991 (Barel-Cohen et al., 2006). The Lower Jordan River extends between the Alumot-dam (approximately $210 \mathrm{~m}$ below sea level) and the Dead Sea (approximately $417 \mathrm{~m}$ below sea level) with a catchment area of about $15,000 \mathrm{~km}^{2}$ (Salameh 1996). The river is about $105 \mathrm{~km}$ long with approximately $190 \mathrm{~km}$ meandering distance (Hamberg, 2000). The characteristics of the Lower Jordan River are much different than those of the Upper Jordan River. While the Upper Jordan River is a source of drinking water, the major water sources of the Lower Jordan River are the Saline Water Carrier and the effluents from the Bitania wastewater treatment plant. The Saline Water Carrier contains a mixture of saline spring water diverted from the western shore of the Lake Kinneret and the treated urban sewage effluents. The Bitania source consists of poorly treated waste effluents.

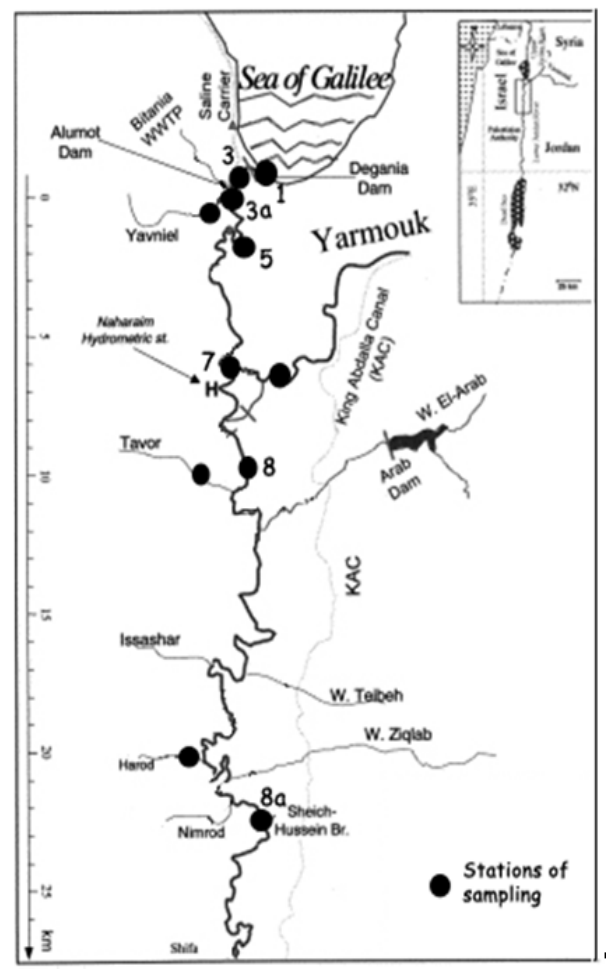

Figure 1. Map of study site

For the purposes of this study, the taxonomic composition of algal assemblages, species densities, and indicator species were determined for the northern part of the Lower Jordan River (Figure 1) between the outlet from the Lake Kinneret (station 1) 
and the Hussein Bridge station (station 8a), as well as for its tributaries (Yavniel, Yarmuk, Harod Tavor, and Bezet Rivers) (Figure 2). Both, the major canal and the tributaries are heavily polluted. The study was conducted during the dry and wet seasons of the summer-dry climate of Israel. The indices of saprobity, water pollution, and self-purification capacities were calculated for all the sampling sites (Sumita, 1986). The algal assemblages of the Lower Jordan River summarily reflect the ecological status and dynamics of the unique river flowing below sea level.
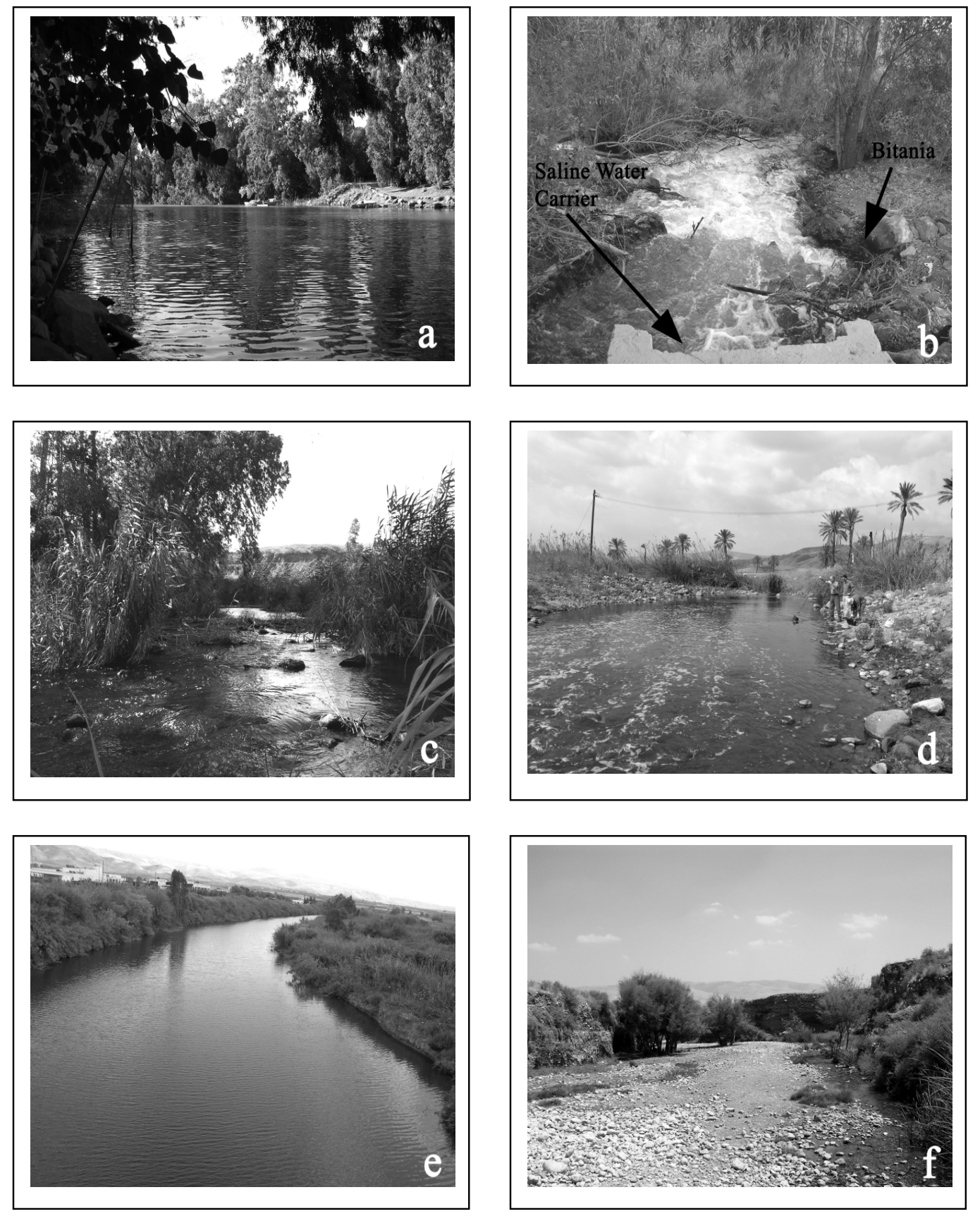

Figure 2. Sampling stations over the Lower Jordan River and tributaries: $a-s t .3 ; b-s t$. Bitania and Salinity Water Carrier; $c-s t .5 ; d-s t .7 ; e-s t .8 a ; f-$ tributary Bezet 


\section{Materials and methods}

For our study we collected 34 samples of planktonic and periphytonic algae from the Lower Jordan River at the end of dry season in November 2005 and at the end of wet season in May 2007. The samples were collected at 13 accessible sampling stations along the Lower Jordan River and its tributaries (Figures 1, 2). The samples were obtained by scooping up for phytoplankton and by scratching for periphyton and fixing in $3 \%$ formaldehyde. The algae were studied with a dissecting Swift microscope under magnifications of 740-1850. The diatoms were prepared with the peroxide technique (Swift, 1967) modified for glass slides (Barinova, 1997). In parallel with the sampling for algae we collected water samples for chemical analyses that are regularly performed by the Ministry of Environment of Israel (Table 1, 2).

Table 1. Environmental variables along the Lower Jordan River in November 2005,

Ec-Electrical conductivity $(\mathrm{mSm} / \mathrm{cm})$, E. coli - cells per 100ml; all other variables in units of $m g /$.

\begin{tabular}{lllllllllllllll}
\hline $\mathbf{2 0 0 5}$ & $\mathbf{k m}$ & $\mathbf{p H}$ & $\mathbf{T}^{\mathbf{0}} \mathbf{C}$ & $\mathbf{E c}$ & $\mathbf{B O D}$ & $\mathbf{C O D}$ & $\mathbf{C l}$ & $\begin{array}{l}\mathbf{N}- \\
\mathbf{k e l}\end{array}$ & $\mathbf{T . P .}$ & $\begin{array}{l}\text { N- } \\
\mathbf{N O}_{3}\end{array}$ & $\mathbf{N O}_{\mathbf{2}}$ & $\mathbf{N H}_{\mathbf{4}}$ & T.N. & $\boldsymbol{E}$ c coli \\
\hline 1 & 0 & 8.23 & 21.6 & 1.08 & 2.9 & 44 & 287 & 0.9 & $<0.2$ & $<1$ & 0.001 & 0.2 & 0.9 & 3100 \\
3 & 1.7 & 7.53 & 18 & 1.41 & 1.9 & 52 & 317 & 1.3 & $<0.2$ & $<1$ & 0.02 & 0.3 & 1.3 & 1300 \\
$3 \mathrm{a}$ & 2.0 & 7.42 & 24.3 & 6.52 & 17 & 76 & 2118 & 9.9 & 3 & $<1$ & 0.16 & 7.1 & 10.1 & 280000 \\
5 & 4.1 & 7.49 & 22.4 & 5.95 & 24 & 88 & 1858 & 7.8 & 2 & $<1$ & 1.1 & 5.8 & 8.9 & 150000 \\
7 & 10.9 & 7.54 & 19.8 & 6.41 & 21 & 75 & 2054 & 7.7 & 3.1 & $<1$ & 1.09 & 6 & 8.8 & 75000 \\
8 & 15.9 & 7.64 & 19.6 & 5.82 & 10 & 36 & 1858 & 2.8 & 2.3 & 3.4 & 1.6 & 1.3 & 7.8 & 2100 \\
$8 \mathrm{a}$ & 40.3 & 7.87 & 19.3 & 6 & 15 & 72 & 1892 & 7.8 & 2.2 & $<1$ & 0.71 & 1.9 & 8.5 & 7300 \\
\hline
\end{tabular}

Table 2. Environmental variables along the Lower Jordan River in May 2007, Ec-Electrical conductivity $(\mathrm{mSm} / \mathrm{cm})$, E. coli - cells per $100 \mathrm{ml}$; all other variables in units of $m g / l$.

\begin{tabular}{lllllllllllllll}
\hline $\mathbf{2 0 0 7}$ & $\mathbf{k m}$ & $\mathbf{p H}$ & $\mathbf{T}^{\mathbf{0}} \mathbf{C}$ & $\mathbf{E c}$ & $\mathbf{B O D}$ & $\mathbf{C O D}$ & $\mathbf{C l}$ & $\begin{array}{l}\text { N- } \\
\text { kel }\end{array}$ & $\mathbf{T . P .}$ & $\begin{array}{l}\text { N- } \\
\text { NO }\end{array}$ & $\begin{array}{l}\text { N- } \\
\text { NO }\end{array}$ & $\mathbf{N H}_{\mathbf{4}}$ & T.N. & E. coli \\
\hline 1 & 0 & 6.60 & 27 & 0.82 & 0.4 & 81 & 241 & 0.9 & $<0.2$ & $<0.2$ & 0.01 & $<0.1$ & 0.9 & 80 \\
3 & 1.7 & 6.90 & 26 & 0.96 & 12 & 50 & 269 & 2.9 & 0.4 & $<0.2$ & 0.018 & $<0.1$ & 2.9 & 170 \\
$3 \mathrm{a}$ & 2.0 & 6.75 & 28 & 6.47 & 20.7 & 72 & 1885 & 17.5 & 4.4 & $<0.2$ & $<0.01$ & 12 & 17.5 & 110000 \\
5 & 4.1 & 7.20 & 26 & 4.63 & 16.5 & 62 & 1949 & 15.9 & 3.6 & $<0.2$ & 0.1 & 9.3 & 16 & 150000 \\
7 & 10.9 & 7.45 & 28 & 5.95 & 30 & 132 & 1914 & 13.7 & 4.2 & $<0.2$ & 0.93 & 4.2 & 14.6 & 11000 \\
8 & 15.9 & 7.50 & - & 5.93 & 18 & 86 & 1914 & 7.2 & 6.1 & 4.4 & 1.42 & 1.3 & 13 & 1400 \\
$8 \mathrm{a}$ & 40.3 & - & - & - & 15 & 102 & 1659 & 5.7 & 1.9 & 3.4 & 0.96 & 1.4 & 10 & 1700 \\
\hline
\end{tabular}

The taxonomy of this study mainly follows the systems adopted in the "Süswasserflora von Mitteleuropa" (Ettl, 1978; Starmach, 1983, 1985; Ettl and Gartner, 1988; Krammer and Lange-Bertalot, 1991a,b,c,d; Komárek and Anagnostidis, 1998), and Green Algae on K.R. (Mattox and Stewart, 1984), with additions for individual taxa (Gollerbach et al., 1953; Desikachary, 1959; Krammer, 1985, 2000; Moshkova and Gollerbach 1986; Lange-Bertalot and Krammer, 1987; Meffert, 1987; Komárek and Anagnostidis, 1989; Popovsky and Pfiester, 1990; Perestenko, 1994; Barber and Carter, 1996; Lenzenweger, 1996; Hegewald, 2000; Rumrich et al., 2000). 
Ecological characteristics of the species are compiled in our database (Barinova et al., 2006a). Our ecological analysis revealed the groups indicator species for $\mathrm{pH}$, salinity, and saprobity level. Each group was separately assessed according to its significance in bio-indication of eutrophication, $\mathrm{pH}$ levels (acidification), salinity, and organic pollutants. The density scores were calculated using the 6-score scale (Korde, 1956) for the saprobity index S, as well as the 5-score scale (Whitton at al., 1991) for the saprobity index EPI.

\section{Saprobity Index $(S)$}

The Saprobity Index (S) was calculated as:

$$
\mathrm{S}=\sum_{i=1}^{n}\left(\mathbf{s}_{i} \cdot \mathrm{a}_{i}\right) / \sum_{i=1}^{n}\left(\mathrm{a}_{i}\right)
$$

where $\mathrm{S}$ - the index of saprobity for the algal community;

$\mathrm{S}_{\mathrm{i}}$ - the species-specific saprobity index;

$\mathrm{a}_{\mathrm{i}}-$ the density score.

$\mathrm{S}$ value between 1 and 4 is the "weighted mean" of all individual indices that defines the self-purification zone corresponding to five classes of water quality (Sládeček, 1973).

This bio-indication approach is based on the ecological classification, which is widely used in European and Asian countries (Romanenko et al., 1990; Whitton et al., 1991; WFD, 2000).

\section{Environmental Pollution Index (EPI)}

An alternative approach to biological assessment of water quality is provided by the diatom-based index of eutrophication and pollution, EPI (Dell'Uomo, 1996) which shows a significant correlation with the chemical and physical properties of the water such as the levels of BOD5, nutrients, conductivity, chlorides, phosphates, etc. In this approach, the indicator species were selected on account of their nutrient level tolerance (Trophic Degree: Dell'Uomo, 1996) and five different organic pollution levels (Sládeček, 1973).

The Environmental Pollution Index (EPI) is calculated as:

$$
E P I=\sum_{j=1}^{n} a_{j} r_{j} i_{j} / \sum_{j=1}^{n} a_{j} r_{j}
$$

where EPI - eutrophication/organic pollution index for the station;

$a_{j}$ - species abundance by the 5 -score scale;

$\mathrm{r}_{\mathrm{j}}$ - constant species index of eutrophication/pollution, EPi;

$\mathrm{i}_{\mathrm{j}}$ - individual coefficient $\mathrm{R}$ for the diatom indicator list (Dell'Uomo, 1996), ranging form 1 to 5 .

The index EPI ranges between 0 and 4, and negatively correlated to such aquatic ecosystem variables as halobity and the trophic level (Dell'Uomo, 1995). The water quality Classes of a sampling station can be estimated on the basis of the intercorrelated variables summed up in Table 3. 
Table 3. Correlation of the saprobity, halobity, trophic level, index EPI and the water quality classes (Dell'Uomo, 1996).

\begin{tabular}{|c|c|c|c|c|c|}
\hline $\begin{array}{l}\text { Saprobic } \\
\text { degree }\end{array}$ & $\begin{array}{l}\text { Trophic } \\
\text { degree }\end{array}$ & Halobic degree & $\begin{array}{c}\text { EPI } \\
\text { range }\end{array}$ & $\begin{array}{c}\text { Class of } \\
\text { water } \\
\text { quality }\end{array}$ & Water quality \\
\hline xenosaprobic & hypotrophic & halophobous & $0.0-0.5$ & 0 & Natural, unpolluted water \\
\hline oligosaprobic & oligotrophic & $\begin{array}{l}\text { oligohalobous- } \\
\text { indifferent }\end{array}$ & $\begin{array}{l}0.5-1.0 \\
1.0-1.5\end{array}$ & I & $\begin{array}{l}\text { Excellent water quality } \\
\text { Good water quality }\end{array}$ \\
\hline$\beta$-mesosaprobic & mesotrophic & $\begin{array}{l}\text { oligohalobous - } \\
\text { indifferent }\end{array}$ & $\begin{array}{l}1.5-2.0 \\
2.0-2.5\end{array}$ & II & $\begin{array}{l}\text { Fairly good water quality } \\
\text { Slightly polluted water }\end{array}$ \\
\hline$\beta$-mesosaprobic & eutrophic & $\begin{array}{l}\text { oligohalobous - } \\
\text { halophilous }\end{array}$ & $\begin{array}{l}2.5-3.0 \\
3.0-3.5\end{array}$ & III & $\begin{array}{l}\text { Rather polluted water } \\
\text { Strongly polluted water }\end{array}$ \\
\hline polysaprobic & hypertrophic & $\begin{array}{l}\text { halophilous - } \\
\text { mesohalobous }\end{array}$ & $3.5-4.0$ & IV & Heavily polluted water \\
\hline
\end{tabular}

The second alternative method of water quality assessment is based on three groups of indicators: saproxenes of clean water, eurysaprobes of medium quality water, and polysaprobes of polluted water defined by Watanabe et al. (1986).

\section{The Integral Index of River Pollution (RPI)}

The integral index of river pollution (RPI; Sumita 1986) was calculated for the entire river flow, based on the DAIpo (Diatom Assemblage Index of Organic Pollution) for each of the sampling stations. This index has been first applied for the rivers of Japan (Watanabe et al. 1986). We adopted RPI for estimating a number of environmental variables of the river flow, based on conductivity, $\mathrm{pH}$, nitrate concentrations, etc. The integral indices (Tavassi at al. 2004; Barinova et al. 2006a) were calculated as:

$$
R P I d=\sum_{i=1}^{n}(D i+D j) * l / 0.5 L
$$

where $\mathrm{Di}, \mathrm{Dj}$ - an estimate of environmental variable or the corresponding index value for adjacent stations $i$ and $j$;

1 - the distance between two adjacent stations $(\mathrm{km})$;

$\mathrm{L}$ - the total length of the river.

\section{The Aquatic Ecosystem State Index (WESI)}

The index of ecosystem status (Aquatic Ecosystem State Index, WESI) is based on the water quality classes (Barinova, et al. 2006a) reflecting the self-purification capacities for each of the sampling stations. It is calculated as:

$$
\text { WESI }=\text { Rank S / Rank N-NO } 3
$$

where: Rank S - rank of water quality based on the Sládeček indices of saprobity.

Rank N-NO ${ }_{3}$ - rank of water quality based on the nitric-nitrogen concentration.

If WESI is equal to or larger than 1, the photosynthetic level is positively correlated with the level of nutrients concentration. WESI is less than 1 would signify that photosynthesis was suppressed, presumably in the consequence of a toxic impact. 
Not only the nitric-nitrogen concentrations, but also the other ecologically significant environmental variables that impacted algal community can be used as the denominator of the WESI equation 4.

\section{Bioassay of Bacteria species}

The ToxScreen Toxicity Test was purchased as a kit from the CheckLight Company (CheckLight Ltd. P.O.Box 72 Qiryat-Tivo'n 36000, Israel). It included lyophilized bacteria, Photobacterium leiognathi, Hydration buffer, Pro-Organic buffer (which favors the detection of organic pollutants), and Pro-Metal buffer (which favors the detection of heavy metal cations). These buffers were developed to enhance the sensitivity of the test to a wide range of agents with different modes of action. The chosen concentrated Assay Buffer (Pro-Metal or Pro-Organic) was diluted in ultra-pure water in which serial dilutions of the tested toxic agent were performed in polystyrene vials. Next, a vial containing the lyophilized luminous bacteria was removed from the freezer, re-hydrated with $1 \mathrm{ml}$ of Hydration Buffer and incubated at $24{ }^{\circ} \mathrm{C}$ for 5 minutes. A suspension of $10 \mu \mathrm{l}$ of cells was dispensed into each vial and thoroughly mixed. Vials were incubated at $24{ }^{\circ} \mathrm{C}$ for 30 minutes, and luminescence was recorded. The bioluminescence index (BI) was determined by the ratio of the bacterial luminescence of water sample from the Lower Jordan River compared to the clean water control sample.

\section{Statistical data analyses}

Statistical analysis was conducted using Statistica 7.0 (StatSoft, 1996). The relationship of diversity data (species richness of a community and of each major taxonomic division Cyanoprokaryota, Bacillariophyta and Chlorophyta that was represented in each community, as well as saprobity index S) with environmental data on the sampling stations estimated by stepwise multiple regression analysis, where numbers of species were used as dependent and the environmental data as independent variables.

\section{Result and discussion}

Benthic algal communities are usually species-rich and therefore represent an information-rich assemblage ideal for environmental monitoring because of their relatively short life cycles, allowing a rapid response to environmental impacts, at the same time revealing a cumulative effect of consecutive environmental events a longer period of time (Janauer and Dokulil, 2006). Because of this, algal bio-indication is included in the EC-Water Framework Directive (WFD, 2000) for water quality assessment and monitoring.

\section{Water quality conditions}

There is an abrupt increase of electric conductivity, chloride, BOD, ammonium, $E$. coli, and in total phosphorus and nitrogen in the lower section (after the Alumot-dam) relative to the upper section (station 1 and 3), which is blocked by the Alumot-dam (Tables 1, 2). This increase could be related to the effluents of Saline Water Carrier and 
the Bitania wastewater treatment plant, which are the major water sources at the inlet of the Lower Jordan River after the Alumot-dam. As a whole, the Lower Jordan River is alkaline, temperate, fresh in the upper section, and brackish in the lower section. According to the water quality estimates, the upper section can be considered unpolluted while the lower section has a high level of BOD, nitrogen, phosphorus, etc., and is considered heavily polluted.

\section{Taxonomy}

We recognized 105 species of algae from nine taxonomical divisions in November 2005; and 86 species of algae from six taxonomical divisions in May 2007. Altogether, for both years we identified 152 species (Tavassi et al., in press) in 34 samples of plankton and periphyton collected from 13 stations over the Lower Jordan River and its tributaries (Table 4). During the study period, the diatoms (Bacillariophyceae) were accompanied by the greens (Chlorophyta) and blue-greens (Cyanoprokaryota) with the euglenoids (Euglenophyta) next in abundance. In 2005, the chrysophytes (Chrysophyta), Xanthophyta, Dinophyta, Cryptophyta, and Rhodophyta were represented by only one or two species each, while in 2007 Dinophyta were represented by 3 species and Cryptophyta by one, which reflected the differences in species composition in dry and wet seasons: in the wet season the diversity is higher. Of 152 species, $135(89 \%)$ are indicators of environmental conditions such as habitats, temperature, streaming and oxygenation, saprobity, halobity, and acidification.

Table 4. Taxonomical distribution of algal indicators diversity over the stations of the Lower Jordan River

\begin{tabular}{lccccccc}
\hline Station at the cannel & $\mathbf{1}$ & $\mathbf{3}$ & $\mathbf{3 a}$ & $\mathbf{5}$ & $\mathbf{7}$ & $\mathbf{8}$ & $\mathbf{8 a}$ \\
\hline Distance, km & 0 & 1.7 & 2 & 4.1 & 10.9 & 15.9 & 40.3 \\
Cyanoprokaryota & 8 & 10 & 4 & 2 & 2 & 9 & 3 \\
Bacillariophyceae & 4 & 10 & 3 & 3 & 9 & 8 & 3 \\
Chlorophyta & 14 & 15 & 2 & 2 & 1 & 5 & 9 \\
Chrysophyta & 1 & 1 & 0 & 0 & 0 & 0 & 0 \\
Dinophyta & 1 & 1 & 0 & 0 & 0 & 1 & 1 \\
Euglenophyta & 1 & 2 & 0 & 0 & 1 & 0 & 0 \\
Cryptophyta & 0 & 1 & 0 & 0 & 0 & 0 & 0 \\
Rhodophyta & 0 & 0 & 0 & 0 & 0 & 1 & 0 \\
No of Species & 29 & 40 & 9 & 7 & 13 & 24 & 16 \\
\hline
\end{tabular}

The dynamic of algal divisions over the stations (Table 4) shows a significant decrease in both high taxa and species diversities in the lower section, from seven divisions with 40 species at station 3 (above the Alumot-dam) to only three divisions with 9 species at station 3 a (below the Alumot-dam). These dynamics represent the marked differences between the upper and lower sections, which persisted round the year (Figure 3). 


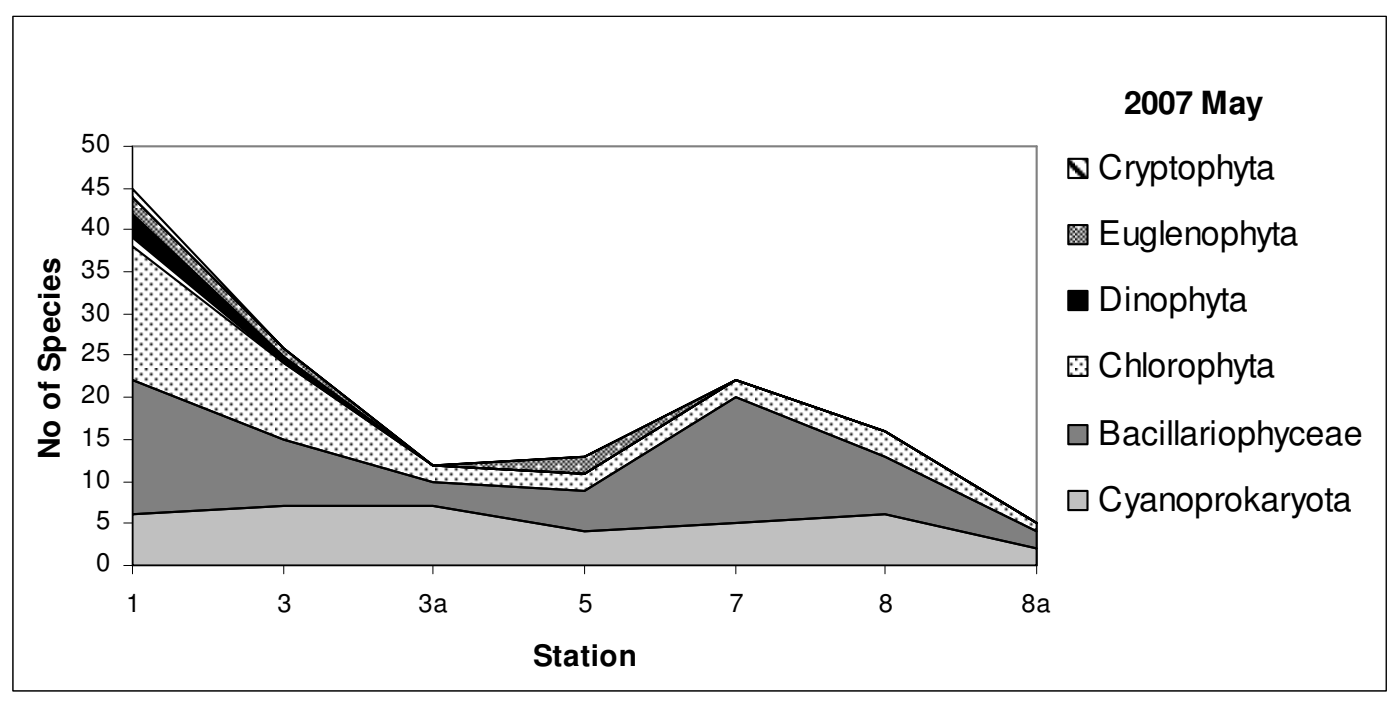

Figure 3. Distribution of taxonomical diversity over the sampling stations of the Lower Jordan River

Chloride concentrations (reflecting salinity load) measured at all sampling stations (Table 1, 2, Figure 4), show that the river is fresh water in the upper section (stations 1 and 3, Figure 2a) and highly brackish in the lower section, after the Alumot-dam, where the Saline Water Carrier and Bitania wastewater treatment plant are discharging water to the river. Figure 5 shows distribution of algal bio-indicators along the Lower Jordan River in relation to chloride concentrations. The upper section, at stations 1 and 3, is dominated by freshwater species, 97\% and 92\%, respectively. However, in the lower section (after the Alumot-dam), at stations $3 a$ (Figure 2b) and 5 (Figure 2c), there is a sharp decrease in freshwater species (to 57\%), accompanied by a decrease in the number of species (Figure 3). A recovery of the total algal diversity and the numbers of freshwater species was observed at station 7, $10.9 \mathrm{~km}$ after the Alumot-dam.

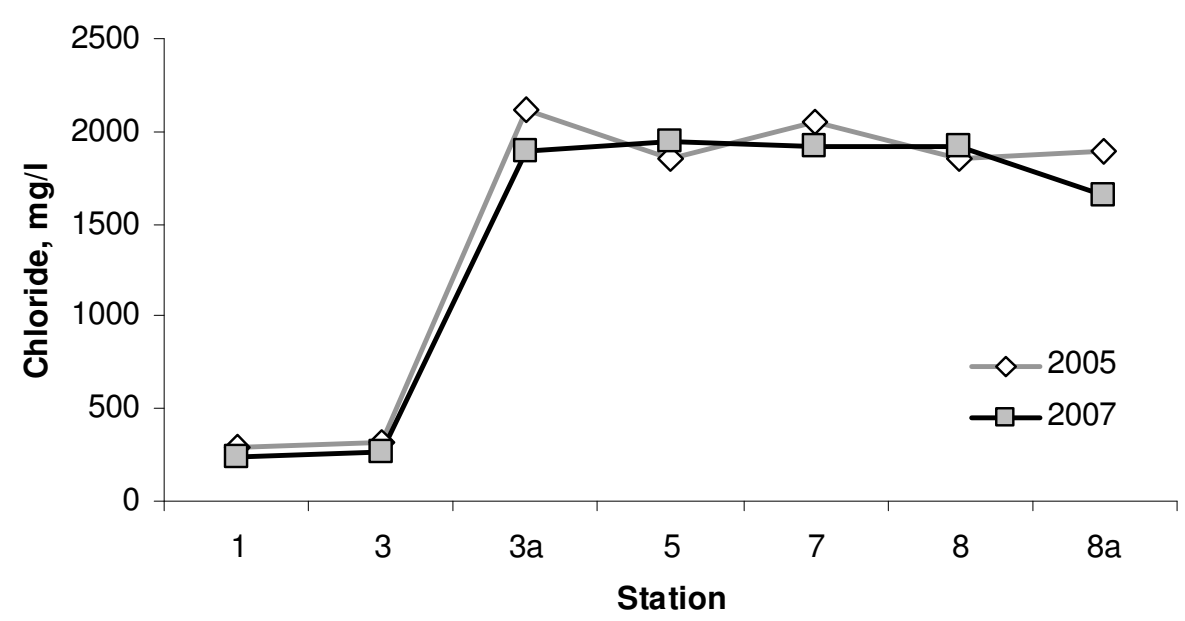

Figure 4. Seasonal Chloride fluctuations over the Lower Jordan River stations 


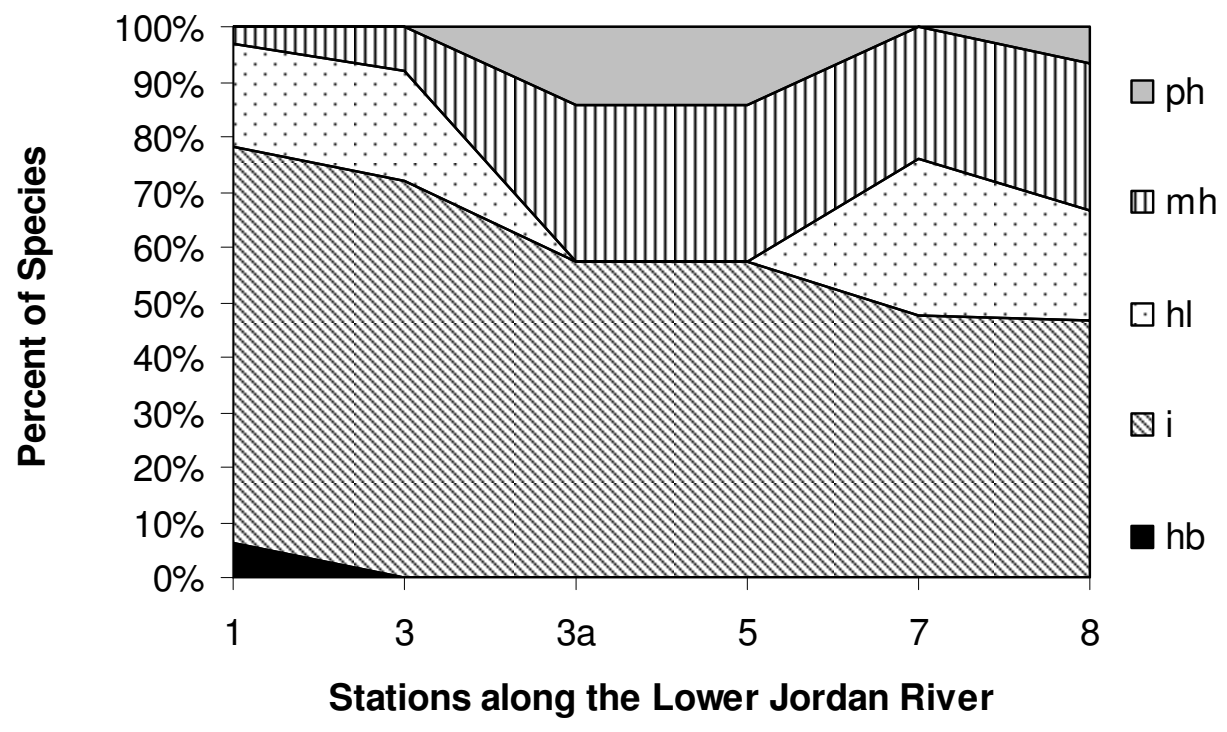

Figure 5. Dynamic of algal species indicators of salinity over the Lower Jordan River stations

The indicators of salinity (86 species, 56.6\%) are assigned to five ecological groups based on the gradient of chloride concentration. The majority of them are "indifferents" (45 species) of a broad tolerance of salinity fluctuations. These include such abundant species as Nitzschia palea, Navicula recens, Plagiotropis lepidoptera (Bacillariophyta), and Cladophora glomerata (Chlorophyta). The less prominent halophiles and mesohalobes were represented by 17 and 18 species, respectively. Remarkably, the algal communities of the Lower Jordan River also contain polyhalobes that prefer marine or brackish waters of a high-chloride concentration. They include Microcoleus chthonoplastes (Cyanoprokaryota) and Enteromorpha torta (Chlorophyta), which were found at the lower section (after the Alumot-dam). The group ratios suggest a wide range of salinity.

\section{Saprobity}

The indicators of organic pollution are assigned to 13 groups of Pantle-Buck's (1995) system. They included 60 species (57\%) in 2005 and 57 species (66\%) in 2007. In 2005 , the most representative among them were the main groups of oligo-, oligobeta- and beta-mesosaprobionts (7, 8, and 16 species, respectively), while in 2007 the main groups were oligo- and beta-mesosaprobionts ( 9 and 13 species, respectively). The transitional groups were less prominent. Such a distribution attests to a high heterogeneity of the Lower Jordan River Basin in respect of organic pollution. Ecological dominants for different groups of saprobionts are: Navicula viridula, Bacillaria paxillifer and Caloneis amphisbaena (Bacillariophyta) among the oligosaprobionts, Navicula recens (Bacillariophyta) and Lyngbya kuetzingii (Cyanoprokaryota) among the oligo-beta-saprobionts, and Phormidium ambiguum, Aphanizomenon flos-aquae and Phormidium autumnale (Cyanoprokaryota) among the beta-saprobionts. Figure 6 shows the dynamics of algal indicators of organic pollution over the Lower Jordan River. In the upper section, at stations 1 and 3, the dominant 
species are indicators of a good to moderate water quality Classes. The indicators of pure water are represented by only one, two, or three species at each station. However, at stations 3a and 5, we observed a sharp decrease in number of good to moderate quality indicators. Their recovery coincided with that of the total diversity and salinity indicators at station 7, $10.9 \mathrm{~km}$ after the Alumot-dam (Figure 2d).

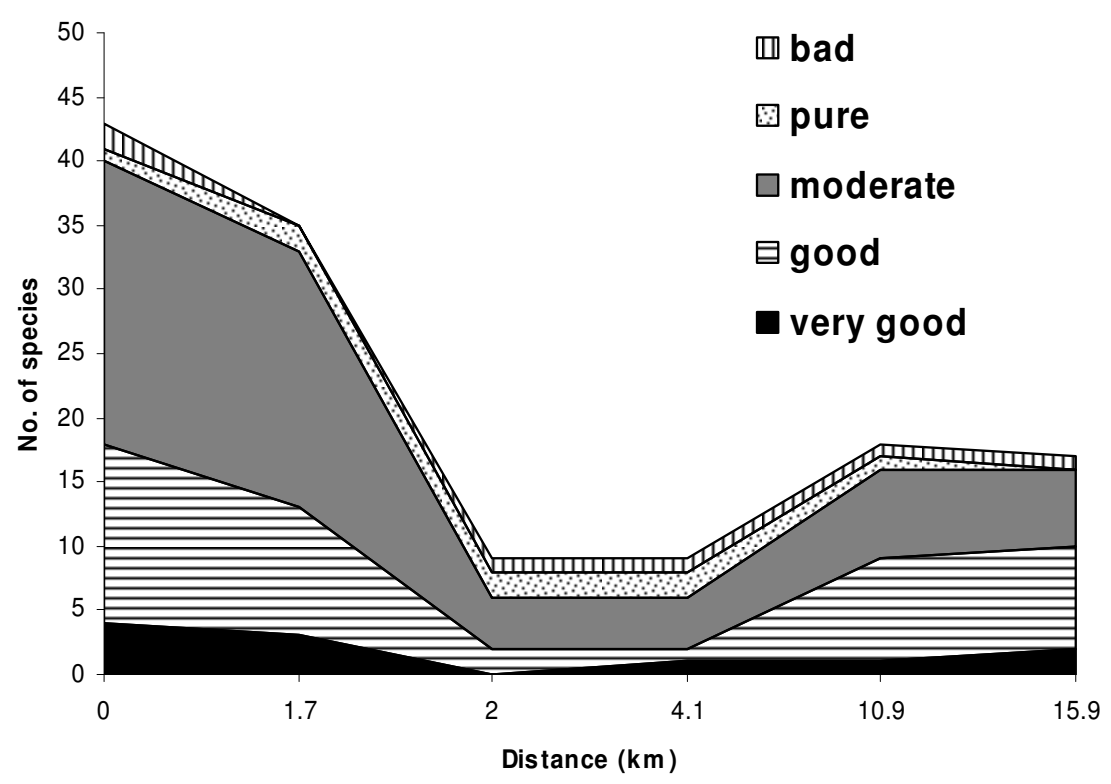

Figure 6. Dynamics of algal indicators of organic pollution over the Lower Jordan River stations

\section{Indices $S$}

The saprobity indices calculated for each of the sampling stations (Equation 1) reflect organic pollution levels that vary from 1.46 to 2.14 in the rainy season and from 1.39 to 2.19 in the dry season (Figure 7). The amplitude of variation falls in the rank of the oligo- to betamesosaprobic self-purification zones attesting to the water quality Class III of moderately polluted waters at the outlet decreasing to Class II at the lowermost river stations 7 (Figure $2 d$ ) and 8. The range of variations decreases down the river, peaking at the station $3 \mathrm{a}$, which indicates a contribution of wastewaters from Bitania and the Salinity Water Carrier. The pollution levels are relative stable in the upper section, while the higher fluctuations were found in the lower section, almost 40 $\mathrm{km}$ long, with an appreciable to self-purification tendency. In the tributaries of the Lower Jordan, the indices of saprobity $\mathrm{S}$ widely varied: 1.79 in Bitania, 1.33-1.58 in Salinity Water Carrier outflow, 1.51-1.80 in Yarmuk, 0.8-1.53 in Tavor, 1.71-2.49 in Harod, 1.34-1.47 in Bezet. In the tributaries the haviest pollution was observed during the rainy season. The Harod River that flow to the Lower Jordan River from the Yehudea Mountain was dramatically polluted by the outwash from the sheep's pasture in May, 2007. 


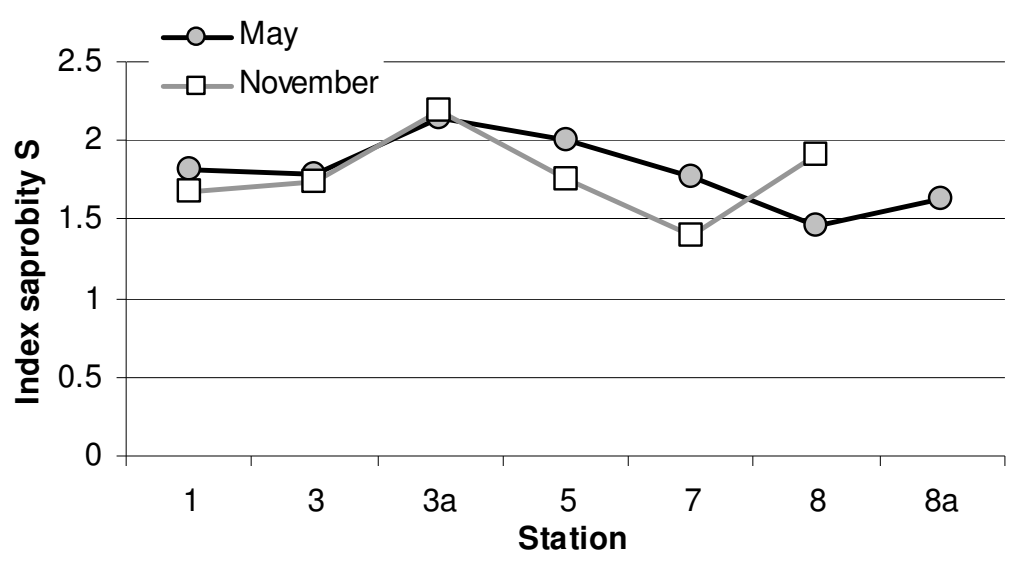

Figure 7. Seasonal dynamics of saprobity indices $S$ over the Lower Jordan River stations

\section{Indices EPI}

The same bio-indication methods were used for the Kishon, Yarqon, Hadera and Alexander rivers in northern Israel (Barinova et al., 2004, 2005, 2006b,c; Tavassi et al., 2004). For comparison with the other Mediterranean regions we used Dell'Uomo's (1995) calculation of EPI (Equation 2). The results are presented in Figure 8 showing the EPI's variation from 1.0 to 4.5 that indicate unpolluted to heavily polluted waters. The algal communities reveal the oligosaprobic to polysaprobic self-purification ranks and the oligotrophic to hypertrophic levels (Dell'Uomo, 1995; Table 3). The trend lines of both seasonal distributions are similar (Figure 8) and reveal two different parts of the canal - the upper, above the Alumot-dam, and the lower below it. As a whole, the fluctuations of EPI's are unconformable to those of S, the ranges are wider and the maxima are displaced in the direction of the heavier polluted alfameso- to polysaprobic waters. Even greater discrepancies were found between S and EPI in the case of pollution estimates. The EPI does not discriminate between the pollution levels at the upper station 1 and the lower stations 5, 7 and 8, which differ from all the other estimates, at the some time not responding to a sharp increase in pollution immediately after Bitania wastewater inflow.

On the other hand, the number of indicator species that are included in the equation of EPI was too low - from 0 to 4 for each community, which makes the results unconvincing in our case. The EPI is based on the diatoms alone, whereas the index $\mathrm{S}$ involves a greater diversity of algal groups and is, therefore, more reliable. We come to similar conclusions in the case of the Yarqon River communities (Tavassi et al., 2004). 


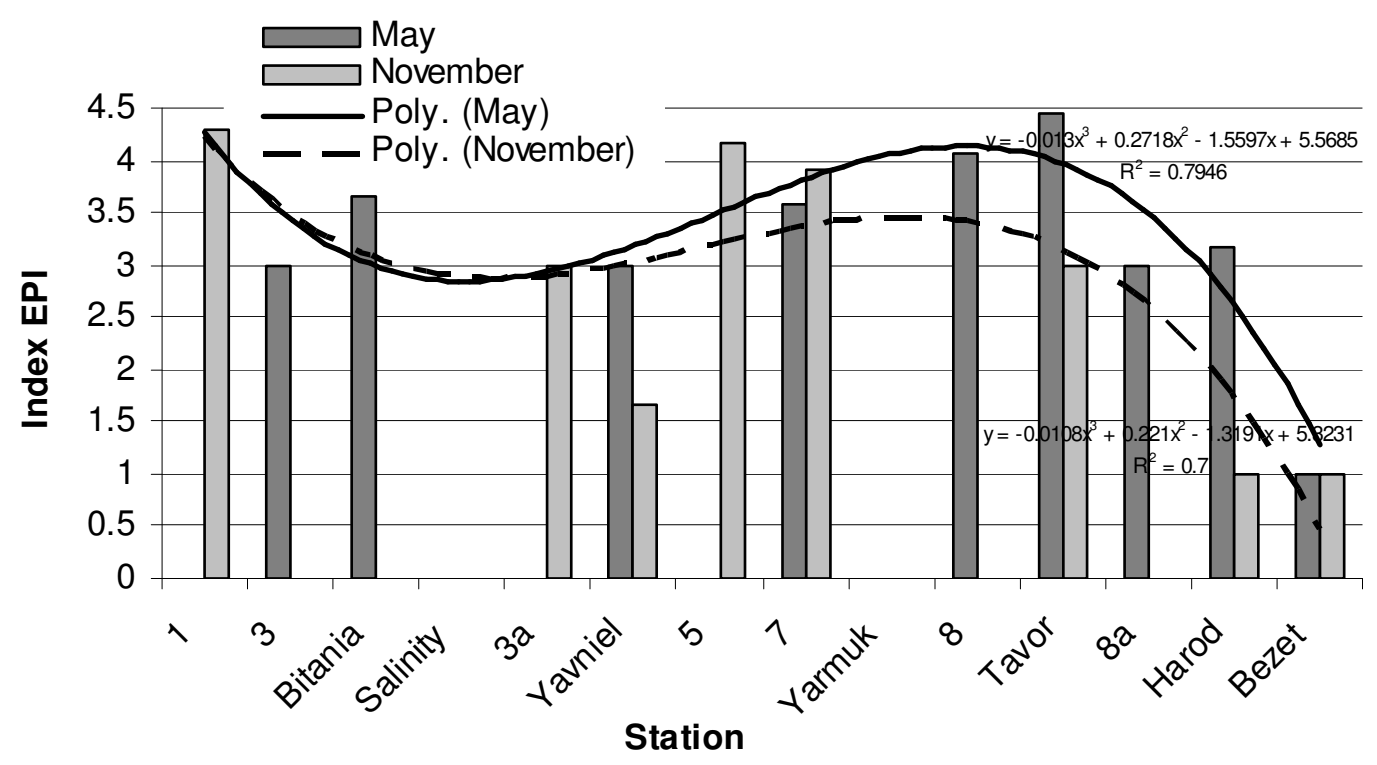

Figure 8. Seasonal dynamics of saprobity indices EPI over the Lower Jordan River and tributaries

\section{RPI indices}

Table 5 presents the results of our calculations of RPI (Equation 3), after Sumita (1986) and Barinova et al. (2006a), for the Lower Jordan River. The RPI includes organic nitrogen $(\mathrm{N}-\mathrm{kel}$.$) , BOD, \mathrm{COD}$, chloride $(\mathrm{Cl})$, total phosphorus $(\mathrm{P})$, nitrate $\left(\mathrm{NO}_{3}\right)$, nitrite $\left(\mathrm{NO}_{2}\right)$, ammonium $\left(\mathrm{NH}_{4}\right)$, and total nitrogen $(\mathrm{N})$. The RPI values in relation to N-kel., COD, $\mathrm{P}$, and $\mathrm{N}$ were high in May 2007 compared to those found in November 2005. These data may indicate a decrease of water quality in the wet season caused by influx of pollution from the basin area. However, in relation to $\mathrm{Cl}$, the RPI values were more stable over the seasons. The major source of chloride is the Saline Water Carrier. Based on RPI stability we conclude that the volume of salt water is nearly the same for the dry and rainy seasons.

Table 5. River Pollution Indices (RPI) based on chemical analysis of the Lower Jordan River

\begin{tabular}{lccccccccc}
\hline \multicolumn{1}{c}{ RPI } & N-kel. & BOD & COD & Cl & T.P. & N-NO & N-NO & NH $_{\mathbf{4}}$ & T.N. \\
\hline November 2005 & 6.36 & 17.64 & 69.48 & 1770 & 2.30 & 1.38 & 0.98 & 4.62 & 7.87 \\
May 2007 & 12.22 & 20.92 & 92.76 & 1729 & 3.89 & 0.86 & 0.60 & 5.28 & 13.49 \\
\hline
\end{tabular}

\section{Statistical analysis}

For the Multiple Regression Analysis we clustered the environmental variables into three major groups. Group 1 includes the macro-variables $\mathrm{pH}, \mathrm{T}^{\circ} \mathrm{C}(\mathrm{T}), \mathrm{Ec}, \mathrm{Cl}, \mathrm{NH}_{4}$. Group 2 includes the variables, which show the of ecosystem processes BOD, COD, 
$\mathrm{NH}_{4}$, T.N. (TN) E. coli. Group 3 includes trophic variables N-kel.(Nk), T.P. (TP), N$\mathrm{NO}_{3}\left(\mathrm{NO}_{3}\right), \mathrm{N}-\mathrm{NO}_{2}\left(\mathrm{NO}_{2}\right)$. The Multiple Regression Analysis indicated a greater range of fluctuations in the algal community relative to the environmental variables (Table 6).

Table 6. Multiple regression coefficients $\left(R^{2}\right)$ of algal community parameters as dependent variables with environmental variables as independent factors in the Lower Jordan River stations in 2005-2007 ( $p: * \leq 0.05 ; * * \leq 0.01 ; * * * 0.001)$

\begin{tabular}{|c|c|c|c|c|c|}
\hline \multicolumn{6}{|c|}{ Group 1: pH, $\mathbf{T}^{\circ} \mathrm{C}(\mathrm{T}), \mathbf{E c}, \mathrm{Cl}, \mathrm{NH}_{4}$} \\
\hline & Step 1 & Step 2 & Step 3 & Step 4 & Step 5 \\
\hline Cyanoprokaryota & - & - & - & - & - \\
\hline Bacillariophyceae & - & - & - & - & - \\
\hline & $\mathrm{Cl}$ & $\mathrm{Cl} \mathrm{T}$ & $\mathrm{Cl} \mathrm{T} \mathrm{NH} 4$ & $\mathrm{pH} \mathrm{T} \mathrm{Cl} \mathrm{NH} 4$ & \\
\hline Chlorophyta & $0.77 * * *$ & $0.83 * * *$ & $0.82 * * *$ & $0.81 * * *$ & - \\
\hline & & $\mathrm{Cl} \mathrm{T}$ & $\mathrm{Cl} \mathrm{T} \mathrm{pH}$ & $\mathrm{Cl} \mathrm{T} \mathrm{pH} \mathrm{NH} 4$ & \\
\hline No of Species & $0.69 * * *$ & $0.70 * * *$ & $0.69^{* *}$ & $0.67 * * *$ & - \\
\hline Index $S$ & - & - & - & - & - \\
\hline \multicolumn{6}{|c|}{ Group 2: BOD, COD, NH $_{4}$, T.N. (TN), E. coli } \\
\hline & $\begin{array}{l}\text { Step } 1 \\
\text { COD }\end{array}$ & Step 2 & Step 3 & Step 4 & Step 5 \\
\hline Cyanoprokaryota & $0.25^{*}$ & - & - & - & - \\
\hline Bacillariophyceae & - & - & - & - & - \\
\hline & $\mathrm{TN}$ & $\begin{array}{l}\text { T.N. } \\
\text { BOD }\end{array}$ & TN BOD E.coli & $\begin{array}{l}\text { TN BOD NH} \\
\text { E.coli }\end{array}$ & $\begin{array}{l}\text { TN BOD NH} \\
\text { COD E.coli }\end{array}$ \\
\hline Chlorophyta & $\begin{array}{l}0.74 * * * \\
\text { TN }\end{array}$ & $0.80^{* * *}$ & $0.79 * * *$ & $0.81 * * *$ & $0.81 * *$ \\
\hline No of Species & $\begin{array}{l}0.59 * * * \\
\text { E.coli }\end{array}$ & - & - & - & - \\
\hline Index S & $0.29 *$ & - & - & - & - \\
\hline \multicolumn{6}{|c|}{ Group 3: N-kel. (Nk), T.P. (TP), N-NO $\left(\mathrm{NO}_{3}\right), \mathrm{N}-\mathrm{NO}_{2}\left(\mathrm{NO}_{2}\right)$} \\
\hline & Step 1 & Step 2 & Step 3 & Step 4 & Step 5 \\
\hline Cyanoprokaryota & - & - & $\mathrm{Nk} \mathrm{TP} \mathrm{NO}_{3}$ & - & - \\
\hline Bacillariophyceae & - & - & $0.43 *$ & - & - \\
\hline Chlorophyta & & $\begin{array}{l}\mathrm{Nk} \mathrm{NO}_{2} \\
0.76^{* *}\end{array}$ & $\begin{array}{l}\mathrm{Nk} \mathrm{NO}_{2} \mathrm{NO}_{3} \\
0.77 * * *\end{array}$ & $\begin{array}{l}\mathrm{Nk} \mathrm{NO}_{3} \mathrm{NO} 2 \mathrm{TP} \\
0.78 * *\end{array}$ & - \\
\hline No of Species & $\begin{array}{l}\mathrm{Nk} \\
0.41 * *\end{array}$ & $\begin{array}{l}\mathrm{Nk} \mathrm{NO}_{3} \\
0.60 * *\end{array}$ & $\begin{array}{l}\mathrm{Nk} \mathrm{NO}_{3} \mathrm{TP} \\
0.64 * *\end{array}$ & $\begin{array}{l}\mathrm{Nk} \mathrm{TP} \mathrm{NO}_{3} \mathrm{NO}_{2} \\
0.66 * *\end{array}$ & - \\
\hline Index $S$ & - & - & - & - & - \\
\hline
\end{tabular}

The most significant correlation is established for the species richness of entire communities, in particular the diversity of green algae, with salinity (negative) and the total and organic nitrogen concentrations (positive). The effect of temperature, nitrates, ammonia and $\mathrm{pH}$ is less significant, but still recognizable. The blue-green algae are influenced by COD, whereas the impact of other variables is insignificant. The diatom diversity depends on the trophic conditions (positive) in the first place. The saprobity index $\mathrm{S}$ is correlated with the abundance of $E$. coli alone (positive). But it is well known that $E$. coli survives in the organically polluted water. 


\section{The Aquatic Ecosystem State Index (WESI)}

WESI conveys a self-purification capacity of aquatic ecosystems. Figure 9 represents the results of WESI calculation (Equation 4) for the Lower Jordan River. The variables we used in this case are the saprobity index $S$ and the ammonia concentration rate for each canal station. During both seasons, the WESI shows similar dynamics. At the upper stations 1 and 3, the WESI remained above one round the year, which led us to conclude that the river ecosystem was sustainable within the normal ranges of selfpurification. In contrast, in the polluted section of the river canal between stations $3 a$ and $8 a$, the WESI was constantly below one indicating a suppressed self-purification process.

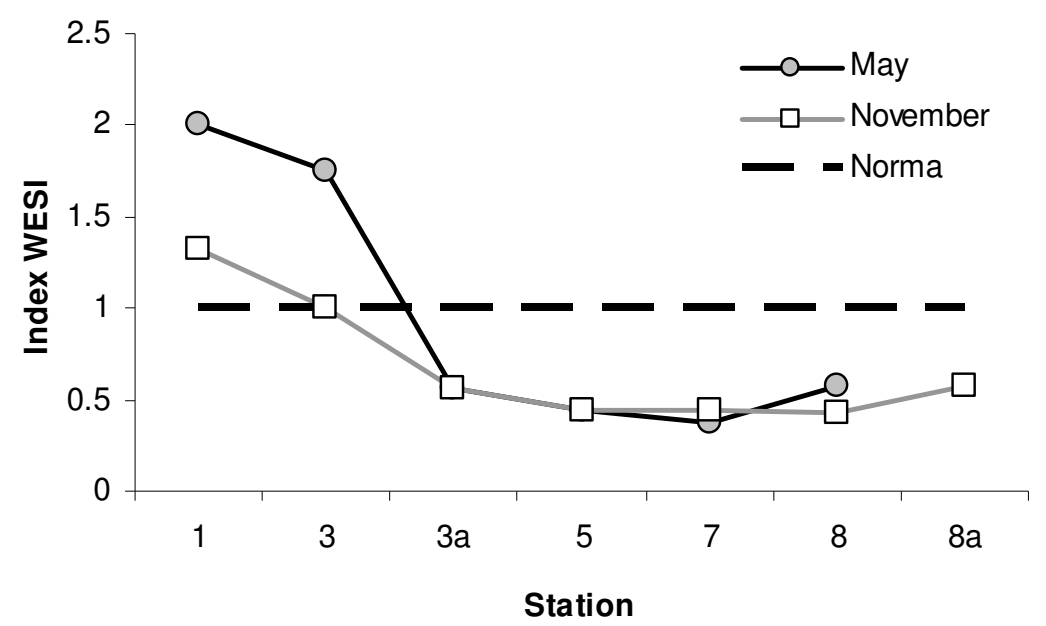

Figure 9. Seasonal dynamics of integral ecosystem indices WESI over the Lower Jordan River stations

\section{Bioluminescence indices (BI) of toxicity}

A highly sensitive stain of a luminescent bacterium, Photobacterium leiognathi, was used to measure water toxicity level of the Lower Jordan River. The action of water pollution on the bacterial luminescence was estimated with the bioluminescence index (BI). In the Pro-Metal buffer (favoring detection of heavy metal cations), the BI value increased up to $200 \%$ compared to the control sample. Evidently the Pro-Metal buffer renders the bacteria too sensitive to organic matter in the water and therefore of little utility in estimating the toxicity levels. Better results we obtained with the Pro-Organic buffer (favoring detection of organic pollutants), for which a treatment of luminous bacteria with water from the upper section (stations 1 and 3) had a slight influence on bioluminescence intensity, with the BI values 0.67-0.81. Below Bitania and the Saline Water Carrier (stations $3 a-8$ ) the BI values $0.38-0.53$ indicated an increase toxicity level.

Figure 10 demonstrates correlation between BI and Electrical conductivity. Our results suggest that inhibition of bacterial luminescence may reflect the level of pollution by the waste and saline waters from Bitania and the Saline Water Carrier. Moreover, our results imply that the level of inhibition can be used for classification of water quality. The BI $>0.5$ indicates a good water quality, whereas the range of $0.5<$ $\mathrm{BI}<0.1$ corresponds to a fair water quality. 


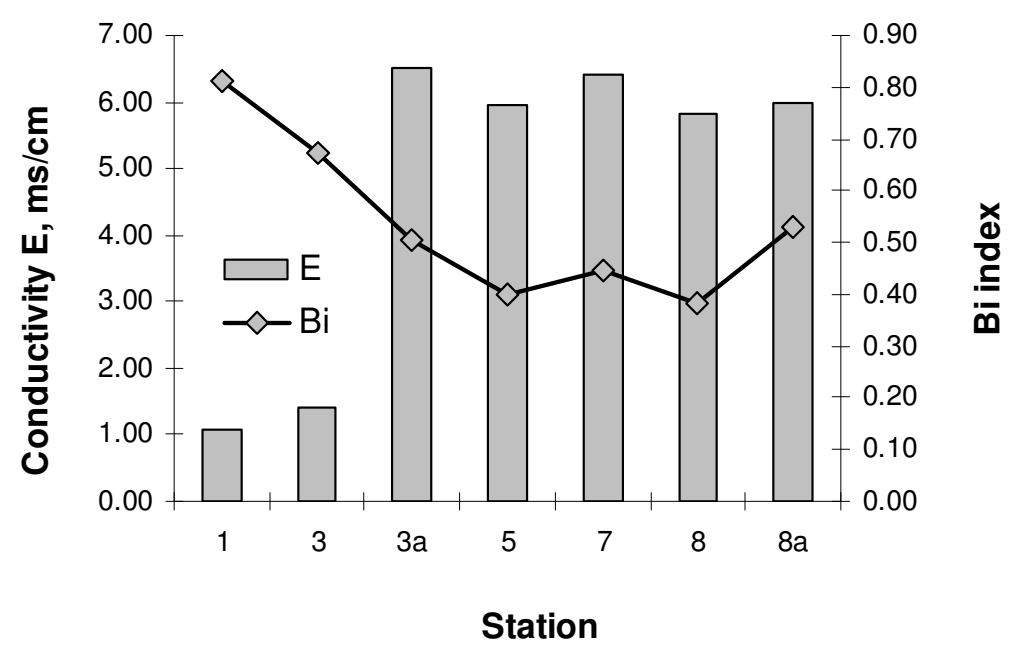

Figure 10. Comparison of toxicity indices BI and Electrical conductivity over the Lower Jordan River stations

Nearly identical BI values were obtained for stations 1 and 3 of the main canal and for the tributaries Yavniel, Tavor, and Yarmuk, whereas a fair water quality was estimated for main canal from Bitania and the Saline Water Carrier till station 8. Selfpurification resumes only at the station $8 a$ down the river.

A comparison of BI and saprobity indices $\mathrm{S}$ over the river canal stations shows (Figure 11) that that indices are a negative correlated: an increase in $\mathrm{S}$ below Bitania is accompanied by an appreciable decrease of BI. And vice versa, a self-purification trend of the lower reaches corresponds to a considerable decrease of $S$ (trend lines in Figure 10).

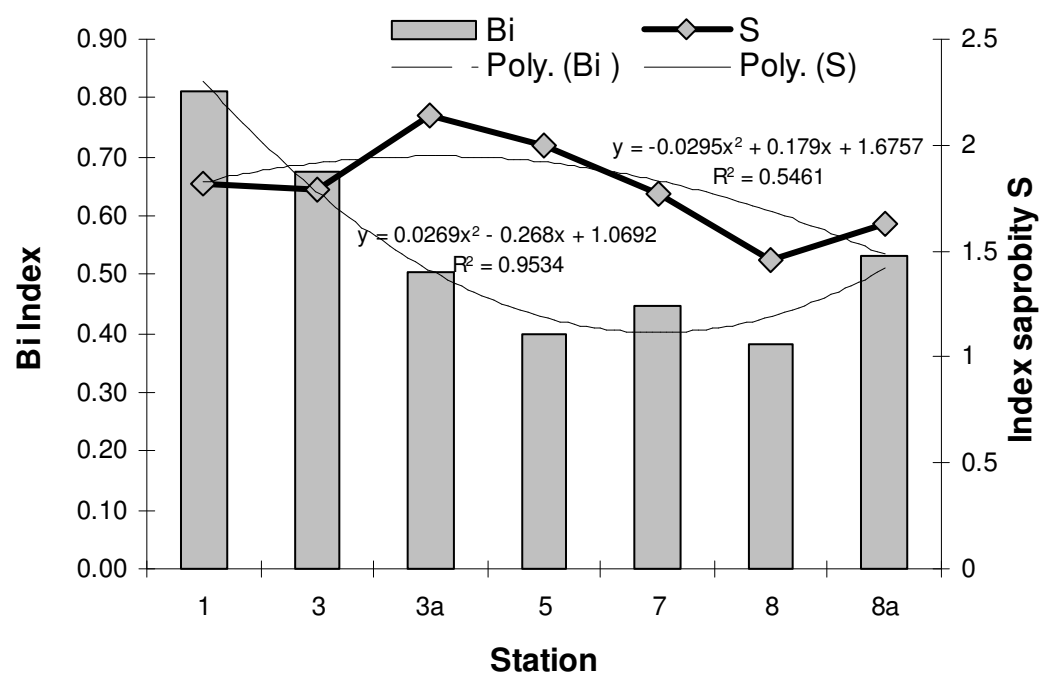

Figure 11. Comparison of saprobity index $S$ and toxicity index BI over the Lower Jordan River stations 


\section{Conclusion}

On the basis of bio-indication analysis, the Lower Jordan River is characterized as alkaline, temperate, with fresh water in the upper reaches (below the Alumot-dam), and brackish in the lower reaches. Pollution is insignificant in the upper reaches, but the high levels of BOD, nitrogen, and phosphorus indicate a dramatic increase in pollution down the river.

During the study period (November 2005 \& May 2007) we identified 152 algal species of plankton and periphyton from seven taxonomic divisions. The algal flora is dominated by the diatoms (Bacillariophyceae), with the greens (Chlorophyta) and bluegreens (Cyanoprokaryota) next in abundance, and followed by the euglenoids (Euglenophyta). The other divisions are represented by only one or two species each. The differences in the species diversity observed in 2005 and 2007 reflect the seasonal changes. Diversity is higher in the dry season. We selected 135 species (89\%) as indicators of environmental conditions. Bio-indicators of chloride concentrations divide the river flow into two sections: one above Alumot-dam in inhabited by freshwater species, whereas polyhalobes appear below the dam indicating an influx from the Saline Water Carrier and Bitania. The typical polyhalobes are Microcoleus chthonoplastes (Cyanoprokaryota) and Enteromorpha torta (Chlorophyta).

The saprobity index $\mathrm{S}$, which reflects organic pollution, varied from 1.46 to 2.14 in the dry season and from 1.39 to 2.19 in the rainy season. In the upper section, the pollution levels are low and relatively stable, while the grater fluctuations with a tendency of self-purification, were observed over the $40 \mathrm{~km}$ length of the lower section. The Mediterranean saprobity index EPI was of little utility in this case because the relatively low numbers of indicator species in the Lower Jordan River communities

The RPI values, determined for both seasons, indicate a higher pollution in the wet season compared to the dry season, the differences being related to washout by rain waters. However, the RPI value for chlorides was relatively stable in both seasons.

The indices of ecological status WESI markedly differ for the two parts of the river canal. At the upper unpolluted stations, the self-purification processes are quite active, but decrease below the Alumot-dam where the algal communities are impacted by pollution.

The bioluminescence index (BI) is strongly correlated with the Electrical conductivity and chlorides reflecting the combined action of salinity and organic pollutants, the most important environmental variables for the algal assemblages of the Lower Jordan River. The BI clearly shows the crucial role of the Salinity Water Carrier and Bitania as the major sources of pollution in the river.

The Statistical Multiple Regression Analysis confirmed the significance of salinity as a major impacted factor for the total species richness of the algal communities. The diatoms and greens are mainly positive influenced by trophic conditions, but the green algae are no less sensitive to temperature and $\mathrm{pH}$. The development of cyanobacteria is mainly controlled by COD. The saprobity index $S$ is correlated with the abundance of $E$. coli, which survives in the organically polluted water.

We consider the evaluation of bio-indication indices of water quality as a preparatory stage for a complex biological monitoring of the Jordan River, one of the major transboundary water sources of the East-Mediterranean region. Biological monitoring of human-environment interactions (Dearing et al., 2006) involves a number of bioindication methods and statistic analysis of both natural and anthropogenic variables impacting the self-purification capacity of aquatic communities.

APPLIED ECOLOGY AND ENVIRONMENTAL RESEARCH 8(1): 19-38. http://www.ecology.uni-corvinus.hu • ISSN 15891623 (Print) • ISSN 17850037 (Online) (C) 2010, ALÖKI Kft., Budapest, Hungary 
Acknowledgements. We are thankful to Dr. Tomas Pavlichek, who collaborated in collecting algal samples from the Lower Jordan River. This work has been partly funded by the Ministry of Absorption of Israel.

\section{REFERENCES}

[1] Barber, H.G., Carter, J.R. (1996): An Atlas of British Diatoms. - Biopress Limited Dorchester UK.

[2] Barel-Cohen, K., Shore, L.S., Shemesh, M., Wenzel, A., Mueller, J., Kronfeld-Schor, N. (2006): Monitoring of natural and synthetic hormones in a polluted river. - Journal of Environmental Management 78(1): 16-23.

[3] Barinova, S.S. (1997): Morphology of connective spines in diatom algae of the genus Aulacoseira Thwaites. - Paleontological J. 31(2): 239-245.

[4] Barinova, S.S., Anissimova, O.V., Nevo, E., Jarygin, M.M., Wasser, S.P. (2004): Diversity and Ecology of Algae from Nahal Qishon, Northern Israel. - Plant Biosystems 138(3): 245-259.

[5] Barinova, S.S., Anissimova, O.V., Nevo, E., Wasser, S.P. (2005): Diversity and ecology of phytoplankton and periphyton of the Nahal Oren, Alon Natural Park, Northern Israel. - Algological Studies 116:169-197.

[6] Barinova, S.S., Medvedeva, L.A., Anissimova, O.V. (2006a): Diversity of algal indicators in environmental assessment. - Pilies Studio Tel Aviv (Rus). http://herba.msu.ru/algae/materials/book/title.html 2008.

[7] Barinova, S.S., Tavassi, M., Nevo, E. (2006b): Algal indicator system of environmental variables in the Hadera River basin, central Israel. - Plant Biosystems 140(1): 65-79.

[8] Barinova, S.S., Tavassi, M., Nevo, E. (2006c): Diversity and ecology of algae from Alexander River (Central Israel). - Flora Mediterranea 16: 111-132.

[9] Dearing, J.A., Batterbee, R.W., Dikau, R. (2006): Human-environment interactions: towards synthesis and simulation. - Reg. Environ. Change 6: 115-123.

[10] Dell'Uomo, A. (1996): Assessment of water quality of an Apennine river as pilot study for diatom-based monitoring of Italian watercourses. - Whitton, B.A., Rott, E. (eds). Use of algae for monitoring rivers II. Agence de I'Eau Artois-Picardie Press, Douai Cedex: 65-72.

[11] Dell'Uomo, A. (1999): Use of algae for monitoring rivers in Italy: current situation and perspectives. - Prygiel, J., Witton, B.A., Buckowska, J. (eds). Use of algae for monitoring rivers III. Agence de I'Eau Artois-Picardie Press, Douai Cedex: 165-179.

[12] Desikachary, T.V. (1959): Cyanophyta. - Indian Council of Agricultural Research, New Delhi.

[13] Ehrlich, A. (1995): Atlas of the inland-water diatom flora of Israel. - Isr. Acad. Sci. and Human, Jerusalem.

[14] Ettl, H. (1978): Xanthophyceae 1. Süßwasserflora von Mitteleuropa 3. G. Fischer, Stuttgart, New York.

[15] Ettl, H., Gartner, G. (1988): Chlorophyta II. Tetrasporales, Chlorococcales, Gloeodendrales. Süßwasserflora von Mitteleuropa 10. G. Fischer, Stuttgart, New York.

[16] Gollerbach, M.M., Kossinskaya, E.K., Polansky, V.I. (1953): Blue-green algae. Guide to Freshwater Algae of the USSR 2. - Soviet Science Press, Moscow. (Rus).

[17] Hamberg, D. (2000): Flows in the Lower Jordan River. Report for the Office of National Foundation. 6130-d00.385. Tahal, Israeli Water Div. Office, Israeli Office of National Foundation, Tahal, Tel-Aviv.

[18] Hegewald, E. (2000): New combinations in the genus Desmodesmus (Chlorophyceae, Scenedesmaceae). - Algological Studies 96: 1-18.

[19] Hill, B.H., Herlihy, A.T., Stevenson, R.J., Kaufmann, P.R., McCormick, F.J., Johnson, C.B. (2000): The use of periphyton assemblage data in an index of biotic integrity. - J. N. Am. Benthol. Soc. 19: 50-67.

APPLIED ECOLOGY AND ENVIRONMENTAL RESEARCH 8(1): 19-38. http://www.ecology.uni-corvinus.hu • ISSN 15891623 (Print) • ISSN 17850037 (Online) (c) 2010, ALÖKI Kft., Budapest, Hungary 
[20] Israel Ministry of the Environment http://www.sviva.gov.il/ 23/01/2005.

[21] Janauer, G., Dokulil, M. (2006): Mactophytes and algae in running waters. - Ziglio, G., Siligardi, M., Flaim, G. (eds). Biological monitoring of rivers. John Willey and Sons, Ltd, Chichester, England.

[22] Kolkwitz, R., Marsson, M. (1908): Ökologie der pflanzlichen Saprobien. - Ber. Deutsch. Bot. Ges. 22: 505-519.

[23] Komárek, J., Anagnostidis, K. (1989): Modern approach to the classification system of Cyanophytes 4 - Nostocales. - Arch. Hydrobiol. Suppl. 82(3) (Algological Studies 56): 247-345.

[24] Komárek, J., Anagnostidis, K. (1998): Cyanoprokaryota 1. Teil: Chroococcales. Süßwasserflora von Mitteleuropa 19/1. G. Fischer, Jena Stuttgart Lübeck Ulm.

[25] Korde, N.V. (1956): The methods of biological studies for the bottom deposits of lakes (the field methods of biological analysis). - Freshwater Life in USSR 4(1): 383-413. (Rus).

[26] Körner, Ch., Sarris, D., Christodoulakis, D. (2005): Long-term increase in climatic dryness in the East-Mediterranean as evidenced for the island of Samos. - Reg. Environ. Change 5: 27-36.

[27] Krammer, K. (1985): Morphologische und lichtmikroskopische Merkmale in Mikrometer bereich. Ein Fergleich. - Mikrokosmos 74: 105-109.

[28] Krammer, K. (2000): Diatoms of Europe 4. - ARG Gantner Verlag KG, Königstein.

[29] Krammer, K., Lange-Bertalot, H. (1991a): Bacillariophyceae. Teil 1. Naviculaceae. Süßwasserflora von Mitteleuropa 2/1. G. Fischer, Jena Stuttgart, Lübeck, Ulm.

[30] Krammer, K., Lange-Bertalot, H. (1991b): Bacillariophyceae. Teil 2. Bacillariaceae, Epithemiaceae, Surirellaceae. - Süßwasserflora von Mitteleuropa 2/2. G. Fischer, Jena, Stuttgart, Lübeck, Ulm.

[31] Krammer, K., Lange-Bertalot, H. (1991c): Bacillariophyceae. Teil 3. Centrales, Fragilariaceae, Eunotiaceae. - Süßwasserflora von Mitteleuropa 2/3. G. Fischer, Stuttgart, Jena.

[32] Krammer, K., Lange-Bertalot, H. (1991d): Bacillariophyceae. Teil 4. Achnanthaceae, Kritische Erganzungen $\mathrm{zu}$ Navicula (Lineolatae) und Gomphonema Gesammtliteraturverzeichnis Teil 1-4. - Süßwasserflora von Mitteleuropa 2/4. G. Fischer, Stuttgart, Jena.

[33] Lange-Bertalot, H., Krammer, K. (1987): Bacillariaceae, Epithemiaceae, Surirellaceae. Neue und wenig bekannte Taxa, neue Kombinationen und Synonyme sowie Bemerkungen und Erganzungen zu den Naviculaceae. - Bibl. Diatom. 15: 1-289.

[34] Lenzenweger, R. (1996): Desmidiaceenflora von Österreich 1. - Bibl. Phycol. 101: 1162.

[35] Lipkovsky, E., Barinova, S.S., Nevo, E. (2007): Algal diversity dynamic and ecological mapping of streams in the Upper Jordan River, Northern Israel. - Proceedings of the First International Conf "Bio-indicators in monitoring of freshwater ecosystems" 23-27 October 2006, St. - Petersburg: 128-132.

[36] Mattox, K.R., Stewart, R.D. (1984): Classification on the green algae: a concept based on comparative cytology. - Irvine, D.E., John, D.M. (eds). Systematics of the Green Algae. - Syst. Assoc. Spec. 27: 29-72.

[37] Meffert, M.E. (1987): Planktic unsheathed filaments (Cyanophyceae) with polar and central gas-vacuoles I. Their morphology and taxonomy. - Arch. Hydrobiol/Suppl 76: 315-346.

[38] Moshkova, N.A., Gollerbach, M.M. (1986): Green Algae. Chlorophyta: Ulotrichophyceae (1), Ulotrichales. Flora plantarum cryptogamarum URSS 10. - Nauka Press, Leningrad. (Rus).

[39] Nevo, E., Wasser, S.P. (eds). (2000): Biodiversity of cyanoprocaryotes, algae and fungi of Israel. Cyanoprocaryotes and algae of continental Israel. - Ruggell, ARG Gantner Verlag, Leichtenstein.

APPLIED ECOLOGY AND ENVIRONMENTAL RESEARCH 8(1): 19-38. http://www.ecology.uni-corvinus.hu • ISSN 15891623 (Print) • ISSN 17850037 (Online) (c) 2010, ALÖKI Kft., Budapest, Hungary 
[40] Pantle, E., Buck, H. (1955): Die biologische Uberwachung der Gewasser und die Darstellung der Ergebnisse. - Gas- und Wasserfach 96(18): 1-604.

[41] Perestenko, L.P. (1994): Red algae of the Far-Eastern seas of Russia. - Olga Press, St. Petersburg.

[42] Popovsky, J., Pfiester, L.A. (1990): Dinophyceae (Dinoflagellida). Süßwasserflora von mitteleuropa 6. - Gustav Fisher Verlag, Stuttgart, Jena.

[43] Potapova, M., Charles, D.F. (2003): Distribution of benthic diatoms in US rivers in relation to conductivity and ionic composition. - Freshwater Biology 48: 1311-1328.

[44] Rayss, T. (1951): Les algaes des eaux continentals. Materiaux paur la flore algologique de la Palestine. - Pal. J. Bot. 5: 71-95.

[45] Romanenko, V.D., Oksijuk, O.P., Zhukinsky, V.N., Stolberg, F.V., Lavrik, V.I. (1990): Ecological impact assessment of hydrotechnical constructions on water bodies. Naukova Dumka, Kiev. (Rus).

[46] Rumrich, U., Lange-Bertallot, H., Rumrich, M. (2000): Diatoms of the Andes from Venezuela to Patagonia/Tierra del Fuego. - Gantner Verlag, Ruggell.

[47] Salameh, E. (1996): Water quality degradation in Jordan: Impacts on environment, economy and future generations resources base. - Friedrich Ebert Foundation and Royal Soc for the Conservation of Nature, Amman, Jordan.

[48] Starmach, K. (1983): Euglenophyta - Eugleniny. Flora slodkowodna Polski 3. Panstwowe Wydawnictwo Naukowe, Warszawa, Krakow.

[49] Starmach K (1985) Chrysophyceae und Haptophyceae. - Süßwasserflora von Mitteleuropa 1. G Fischer, Stuttgart, New York.

[50] StatSoft Inc., Statistica for Windows (Computer Program Manual) Tulsa OK (1996).

[51] Sumita, M. (1986): A numerical water quality assessment of rivers in Hokuriku District using epilithic diatom assemblage in riverbed as a biological indicator (II). The values of RPId in surveyed rivers. - Diatom, Japan J. Diatomology 2: 9-18.

[52] Swift, E. (1967): Cleaning diatom frustules with ultraviolet radiation and peroxide. Phycologia 6: 161-163.

[53] Tavassi, M., Barinova, S.S., Anissimova, O.V., Nevo, E., Wasser, S.P. (2004): Algal indicators of the environment in the Nahal Yarqon Basin, Central Israel. - International J. Algae 6(4): 355-382.

[54] Tavassi, M., Barinova, S., Glassman, H. (in press): Algal community in the polluted lower Jordan River, Israel. - Israel J. Plant Science.

[55] Watanabe, T., Asai, K., Houki, A. (1986): Numerical estimation to organic pollution of flowing water by using the epilithic diatom assemblage - Diatom Assemblage Index (DAIpo). - Sci. Total Environ. 55: 209-218.

[56] WFD (2000) Directive 2000/60/EC of the European Parliament and of the Council establishing a framework for community action in the field of water policy. - Official J. Eur. Communities L327, Brussels, Belgium: 1-72.

[57] Whitton, B.A., Rott, E. (eds). (1995): Use of algae for monitoring rivers II. - Institute für Botanik Univ. Press, Innsbruck.

[58] Whitton, B.A., Roth, E., Friedrich, G. (eds). (1991): Use of algae for monitoring rivers. - Institute für Botanik Univ. Press, Innsbruck. 